\title{
Randomised controlled trial to compare safety and efficacy of vaginal versus oral route of misoprostol for induction of labour in term pregnancy with unfavourable cervix
}

\author{
Parminder Kaur ${ }^{1}$, Poonam Goel ${ }^{2}$, Navneet Takkar $^{2}$, Anju Huria ${ }^{2}$ \\ ${ }^{1}$ Department of Obstetrics \& Gynaecology, ESI PGIMSR, New Delhi, India \\ ${ }^{2}$ Department of Obstetrics \& Gynaecology, Government Medical College \& Hospital, Chandigarh, India \\ Received: 19 October 2015 \\ Accepted: 23 November 2015 \\ *Correspondence: \\ Dr. Parminder Kaur, \\ E-mail: saggi.paro@gmail.com \\ Copyright: () the author(s), publisher and licensee Medip Academy. This is an open-access article distributed under \\ the terms of the Creative Commons Attribution Non-Commercial License, which permits unrestricted non-commercial \\ use, distribution, and reproduction in any medium, provided the original work is properly cited.
}

\begin{abstract}
Background: The objective of the study was to compare safety and efficacy of vaginal versus oral route of misoprostol for induction of labour in term pregnancy.

Methods: A total of 100 pregnant women with clinical indication for labour induction and poor bishops score were randomly assigned to receive vaginal or oral misoprostol. Group A received $25 \mu \mathrm{g}$ of misoprostol vaginally (maximum up to 3 doses 4 hourly interval) and group B received $25 \mu \mathrm{g}$ of misoprostol orally (up to 5 doses 2 hourly interval) in solution form. Maternal and fetal outcomes were compared in both groups to assess the safety and efficacy of vaginal versus oral route.

Results: Fifty women received vaginal and 50 women received oral misoprostol. Average interval from induction to active stage was shorter in oral misoprostol $(7.42 \pm 4.2$ hours versus $10.30 \pm 5.1$ hours) $(\mathrm{p}=0.006)$. There was no significant difference $(\mathrm{p}=0.272)$ in the average interval from induction to delivery between the vaginal group $(14.42 \pm 5.01 \mathrm{hrs})$ and oral group $(13.14 \pm 5.5 \mathrm{hrs})$. No significant difference in caesarean section rates $(\mathrm{p}=0.42)$. Incidence of hyperstimulation was significantly higher $(\mathrm{p}=0.025)$ in vaginal group as compared to oral group $(18 \%$ vs $4 \%$ ). Incidence of nausea, vomiting, vaginal or cervical tears and postpartum hemorrhage were comparable in both the groups. There were no statistically significant differences in neonatal outcomes.

Conclusions: Oral misoprostol has a better safety profile than vaginal route as the incidence of hyperstimulation and tachysystole was significantly more in vaginal group, although there were no significant differences in the maternal and neonatal outcomes.
\end{abstract}

Keywords: Vaginal misoprostol, Oral misoprostol, Induction of labour

\section{INTRODUCTION}

Induction of labour is a commonly done obstetrical procedure where labour is started by artificial means. It is indicated when the benefits to either mother or fetus outweigh those of continuing the pregnancy. ${ }^{1}$ Lack of adequate cervical ripening is a known obstacle to successful labour induction and expeditious delivery. ${ }^{2-4}$ There are various methods available for labour induction out of which prostaglandins (misoprostol-synthetic prostaglandin E1 analogue and dinoprostoneprostaglandin E2 analogue) are widely used. ${ }^{5}$ Although dinoprostone is effective method but because of its cost and storage requirements the search of an equally effective, easily stored, affordable labour inducing agent has led to extensive use of misoprostol. ${ }^{6}$ Misoprostol can be used via various routes like vaginal, oral, sublingual and buccal for cervical ripening and labour induction. Although direct local effect of vaginal administration is advantageous, the shorter half-life of oral delivery is beneficial in event of side effects like hyperstimulation. ${ }^{2}$ According to American College of Obstetricians and Gynaecologists (ACOG) committee opinion and WHO guidelines, $25 \mu \mathrm{g}$ should be considered as the initial dose 
if misoprostol for cervical ripening and labour induction at term. ${ }^{7}$ Its use for cervical ripening and labour induction has been studied recently and has been found as effective as vaginal misoprostol in achieving vaginal delivery with a significantly reduced incidence of uterine hyperstimulation with fetal heart rate changes, caesarean section rates and lower risk of APGAR score being less than seven at $5 \mathrm{~min}$ of life although there is scanty literature regarding its use from India. ${ }^{8}$ Apart from the clinical advantages, oral misoprostol would also offer other advantages in terms of dosage accuracy and patient satisfaction, would reduce the need for repeated vaginal examinations and this is more acceptable to women. ${ }^{9}$

\section{METHODS}

One hundred pregnant women requiring induction of labour with unfavourable cervix at term gestation were randomly selected and assigned in two equal groups by computer-generated randomization table. Inclusion criteria were singleton fetus, cephalic presentation, period of gestation 37-41 weeks, reassuring fetal heart rate, Bishop Score $\leq 6$, membranes intact and exclusion criteria were prior uterine scar (previous cesarean section and myomectomy), cephalopelvic disproportion, hypersensitivity to prostaglandins, renal, hepatic or cardiovascular disease, severe asthma, maternal glaucoma, antepartum hemorrhage, intrauterine death or fetal anomaly, patients with severe systemic illness like uncontrolled Diabetes mellitus, eclampsia. All patients were segregated into two groups (group-A receiving vaginal misoprostol and group-B receiving oral misoprostol). Group A women received $25 \mu \mathrm{g}$ of misoprostol (up to 3 doses 4 hourly interval) in posterior fornix of vagina and Group B received $25 \mu \mathrm{g}$ of misoprostol orally (up to 5 doses 2 hourly interval) in solution form in table spoon $(10 \mathrm{ml})$ for induction of labour. Subsequent doses of misoprostol were withheld if regular uterine contractions have been established, a Bishop Score $\geq 8$ has been achieved or active labour has begun. Oxytocin for labour augmentation was given if required. Failed induction was taken as women not reaching active phase of labour or not going in labour inspite of full regimen of misoprostol and oxytocin augmentation. Primary outcome was the interval from induction to vaginal delivery. Secondary outcome variables among labour characteristics were Bishop score in both the groups at time of induction of labour, time interval from induction to active stage, mode of delivery, indications for cesarean delivery, number of emergency caesareans performed for abnormal FHR pattern, number of doses of drugs used, incidence of adverse effects, uterine contraction abnormalities like tachysystole ( $>5$ contractions per 10 minutes for at least 20 minutes without fetal heart changes), uterine hyper systole/hypertonus (single contraction lasting at least two minutes without fetal heart changes), hyper stimulation (tachysystole or hyper systole with fetal heart rate changes such as persistent decelerations, tachycardia or decreased short term variability) and among maternal side effects pyrexia, hyperpyrexia, nausea, vomiting, diarrhoea, incidence of postpartum hemorrhage, cervical tears, and vaginal tears were noted and in fetal outcomes - APGAR score at 1 and $5 \mathrm{~min}$, neonatal jaundice, transient tachypnoea of new born, incidence of meconium stained amniotic fluid, admission to neonatal intensive care unit were compared.

\section{RESULTS}

Table 1: Demographic characteristics in two groups.

\begin{tabular}{|llll|}
\hline & $\begin{array}{l}\text { Group A } \\
\text { (vaginal) } \\
(\mathbf{n}=50)\end{array}$ & $\begin{array}{l}\text { Group B } \\
\text { (Oral) } \\
(\mathbf{n = 5 0})\end{array}$ & $\begin{array}{l}\text { P } \\
\text { Value }\end{array}$ \\
\hline Primigravida & $39(78 \%)$ & $35(70 \%)$ & 0.67 \\
\hline Multigravida & $11(22 \%)$ & $15(30 \%)$ & 0.64 \\
\hline $\begin{array}{l}\text { Mean age } \\
\text { group }\end{array}$ & $25.26 \pm 3.521$ & $25.56 \pm 3.96$ & 0.949 \\
\hline Height & $157.58 \pm 5.8$ & $158.10 \pm 5.5$ & 0.648 \\
\hline Weight $(\mathrm{kg})$ & $59.68 \pm 5.4$ & $60.98 \pm 7.1$ & 0.648 \\
\hline BMI & $24.13 \pm 2.8$ & $24.45 \pm 3.1$ & 0.580 \\
\hline $\begin{array}{l}\text { Period of } \\
\text { gestation } \\
\text { (wks) }\end{array}$ & 38.8 & 38.8 & 0 \\
\hline
\end{tabular}

A total of 100 women were included in study who met the inclusion criteria. They were divided into two groups, in group A vaginal misoprostol $(25 \mu \mathrm{g} 4$ hourly to maximum 3 doses) and in group $B$ oral misoprostol

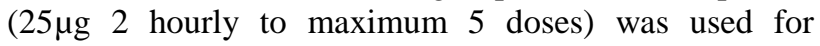
cervical ripening and induction of labour. Patients were selected for vaginal or oral routes of misoprostol according to computer generated random number table.

Table 2: Comparison of durations of stages of labour and induction to active stage and delivery intervals in women who delivered vaginally in two groups.

\begin{tabular}{|llllll|} 
Durations & $\begin{array}{l}\text { Duration of stage } \\
\text { I of Labour (hrs) }\end{array}$ & $\begin{array}{l}\text { Duration of stage } \\
\text { II of Labour } \\
\text { (hrs) }\end{array}$ & $\begin{array}{l}\text { Duration of stage } \\
\text { III of Labour } \\
\text { (min) }\end{array}$ & $\begin{array}{l}\text { Interval between } \\
\text { Induction and } \\
\text { Active Stage (hrs) }\end{array}$ & $\begin{array}{l}\text { Interval between } \\
\text { Induction and } \\
\text { Delivery (hrs) }\end{array}$ \\
\hline Group A & $8.52 \pm 3.6$ & $0.94 \pm 0.43$ & 5.00 & $10.30 \pm 5.1$ & $14.42 \pm 5.01$ \\
\hline Group B & $7.36 \pm 4.1$ & $1.24 \pm 1.2$ & 5.00 & $7.42 \pm 4.2$ & $13.14 \pm 5.5$ \\
\hline P value & 0.186 & 0.145 & & 0.006 & 0.272 \\
\hline
\end{tabular}


In group A $39(78 \%)$ women were primigravida and $11(22 \%)$ multigravida and in group B $35(70 \%)$ were primigravida and $15(30 \%)$ were multigravida and difference is not statistically significant $(\mathrm{P}=0.67$ and 0.64 respectively). Maximum number of women belongs to the age group of 20-30 years. Both groups were comparable in age distribution $(\mathrm{P}=0.949)$. Mean period of gestation was 38.8 weeks in both the groups. Indications of induction of labour were comparable in group $\mathrm{A}$ and group $\mathrm{B} \quad(\mathrm{P}=0.517)$. There was no statistically significant difference $(p=0.43)$ in the two groups as regards the pre induction bishop's score among primigravida. Among primigravida maximum number of women had bishop's score of 4 in both groups. Among multigravida more women in group B had bishop's score of 4-5(14/15 women) as compared to group A (4/11) which was statistically significant (Table 1 ).

Table 3: Comparison of mode of delivery in two groups.

\begin{tabular}{|llll|}
\hline $\begin{array}{l}\text { Mode of } \\
\text { Delivery }\end{array}$ & $\begin{array}{l}\text { Group A } \\
\text { (Vaginal) } \\
(\mathbf{n}=50)\end{array}$ & $\begin{array}{l}\text { Group B } \\
\text { (Oral) } \\
(\mathbf{n}=50)\end{array}$ & $\begin{array}{l}\text { Total } \\
(\mathbf{n}=100)\end{array}$ \\
\hline $\begin{array}{l}\text { Normal } \\
\begin{array}{l}\text { Vaginal } \\
\text { Delivery }\end{array}\end{array}$ & $36(72 \%)$ & $40(80 \%)$ & 76 \\
\hline $\begin{array}{l}\text { Instrumental } \\
\text { Delivery }\end{array}$ & $2(4 \%)$ & $3(6 \%)$ & 5 \\
\hline $\begin{array}{l}\text { Emergency } \\
\text { LSCS }\end{array}$ & $12(24 \%)$ & $7(14 \%)$ & 19 \\
\hline
\end{tabular}

Table 4: Comparison of number of vaginal deliveries occurring within 24 hours of induction in two groups.

\begin{tabular}{|llll|}
\hline & $\begin{array}{l}\text { Group A } \\
\text { (Vaginal) } \\
(\mathbf{n = 3 8 )}\end{array}$ & $\begin{array}{l}\text { Group B } \\
\text { (Oral) } \\
(\mathbf{n = 4 3})\end{array}$ & $\begin{array}{l}\text { Total } \\
(\mathbf{n}=\mathbf{8 1})\end{array}$ \\
\hline $\begin{array}{l}\text { Delivery } \\
\text { within 24 } \\
\text { hrs }\end{array}$ & $37(97.3 \%)$ & $41(95.3 \%)$ & $78(96.3 \%)$ \\
\hline $\begin{array}{l}\text { Delivery } \\
>24 \text { hrs }\end{array}$ & $1(2.7 \%)$ & $2(4.7 \%)$ & $3(3.7 \%)$ \\
\hline
\end{tabular}

Indications of induction of labour included cholestasis of pregnancy, oligohydramnios, preeclampsia, poor biophysical profile, post-dated pregnancy, fetal growth restriction, gestational diabetes mellitus and these were comparable in group A and group $\mathrm{B}(\mathrm{P}=0.517)$. Mean number of doses of misoprostol used in group A was $1.98 \pm 0.87$ and in group B $2.88 \pm 1.08$ with $\mathrm{P}$ value $<.001$ which is statistically significant. Mean number of doses of misoprostol used in primigravida in group A was $2.94 \pm 1.14$ and in group $\mathrm{B}$ was $2.05 \pm 0.92 \quad(\mathrm{P}=0.544)$ which is not significant.
Table 5: Comparison of indications of LSCS in two groups.

\begin{tabular}{|c|c|c|c|c|}
\hline $\begin{array}{l}\text { Indication } \\
\text { of LSCS }\end{array}$ & $\begin{array}{l}\text { Group A } \\
\text { (Vaginal) } \\
(\mathrm{n}=12)\end{array}$ & $\begin{array}{l}\text { Group } \\
\text { B } \\
(\text { Oral }) \\
(n=7)\end{array}$ & $\begin{array}{l}\text { Total } \\
(n=19)\end{array}$ & $\begin{array}{l}\text { P } \\
\text { value }\end{array}$ \\
\hline MSL & $\begin{array}{l}2 \\
(16.7 \%)\end{array}$ & 0 & $\begin{array}{l}2 \\
(10.5 \%)\end{array}$ & \multirow{4}{*}{0.446} \\
\hline FetalDistess & $\begin{array}{l}7 \\
(58.3 \%)\end{array}$ & $\begin{array}{l}3 \\
(42.9 \%)\end{array}$ & $\begin{array}{l}10 \\
(52.6 \%)\end{array}$ & \\
\hline $\begin{array}{l}\text { Failed } \\
\text { Induction }\end{array}$ & $\begin{array}{l}1 \\
(8.3 \%)\end{array}$ & $\begin{array}{l}1 \\
(14.3 \%)\end{array}$ & $\begin{array}{l}2 \\
(10.5 \%)\end{array}$ & \\
\hline NPOL & $\begin{array}{l}2 \\
(16.7 \%)\end{array}$ & $\begin{array}{l}3 \\
(42.9 \%)\end{array}$ & $\begin{array}{l}5 \\
(26.3 \%)\end{array}$ & \\
\hline
\end{tabular}

Table 6: Comparison of side effects in two groups.

\begin{tabular}{|c|c|c|c|}
\hline & $\begin{array}{l}\text { Group A } \\
\text { (Vaginal) } \\
(\mathbf{n}=\mathbf{5 0})\end{array}$ & $\begin{array}{l}\text { Group } \\
\text { B } \\
(\text { Oral }) \\
(n=50)\end{array}$ & $\begin{array}{l}\mathrm{P} \\
\text { value }\end{array}$ \\
\hline \multicolumn{4}{|l|}{ Maternal Side Effects } \\
\hline Nausea \&vomiting & $17(34 \%)$ & $\begin{array}{l}18 \\
(36 \%)\end{array}$ & 0.834 \\
\hline Fever & $4(8 \%)$ & 0 & 0.041 \\
\hline Hyperstimulation & $9(18 \%)$ & $2(4 \%)$ & 0.025 \\
\hline Tachysystole & $12(24 \%)$ & $5(10 \%)$ & 0.062 \\
\hline Hypertonus & $9(18 \%)$ & $1(2 \%)$ & 0.008 \\
\hline $\begin{array}{l}\text { Post } \\
\text { partumhemorrhage }\end{array}$ & $2(4 \%)$ & $3(6 \%)$ & \\
\hline Cervical tears & 0 & $1(2 \%)$ & \\
\hline Vaginal tears & $1(2 \%)$ & $2(2 \%)$ & \\
\hline \multicolumn{4}{|c|}{ Neonatal Complication } \\
\hline Neonatal Jaundice & $3(6 \%)$ & $4(8 \%)$ & \multirow{3}{*}{4.244} \\
\hline $\begin{array}{l}\text { Transient Tachypnoea } \\
\text { of Newborn }\end{array}$ & $4(8 \%)$ & 0 & \\
\hline NICU Care Required & $5(10 \%)$ & $4(8 \%)$ & \\
\hline
\end{tabular}

There was no statistically significant difference in the mean duration of stage I, II and III of labour in both groups, mean duration of stage I of labour was $8.52 \pm 3.6$ hrs, stage II was $0.94 \pm 0.43 \mathrm{hrs}$ and stage III was 5 min in group A. Mean duration of Stage I, stage II and stage II in oral misoprostol group was $7.36 \pm 4.1 \mathrm{hrs}, 1.24 \pm 1.2 \mathrm{hrs}$, $5 \mathrm{~min}$ respectively. There was no statistically significant difference in the induction to delivery intervals between the two groups. However, in oral group the interval between induction to active stage was shorter as compared to vaginal group $(7.42 \pm 4.2 \mathrm{hrs}$ vs $10.30 \pm 5.1$ $\mathrm{hrs})$ and this was statistically significant $(\mathrm{p}=0.006)$. When the study groups were further divided into primigravida and multigravida, still there was no statistically significant difference between mean duration of stage I, II, III and between induction to delivery interval in both the groups (group A \& B) (Table 2). 
In group A, 38(76\%) women and 43(86\%) women in group B delivered vaginally out of which 2 women in group A and 3 in group B had instrumental delivery. In group A $12 / 50$ (24\%) women underwent emergency LSCS in group A and $7 / 50(14 \%)$ in group B but difference among the mode of deliveries in both the groups was statistically insignificant $(\mathrm{P}=0.42)$, although more women required LSCS in group A (Table 3 ).

Table 7: APGAR score at $1 \mathrm{~min}$ in two groups.

\begin{tabular}{|llll|}
\hline $\begin{array}{l}\text { APGAR Score at 1 min } \\
\text { APGAR } \\
\text { Score }\end{array}$ & $\begin{array}{l}\text { Group A } \\
(\text { Vaginal }) \\
(\mathrm{n}=50)\end{array}$ & $\begin{array}{l}\text { Group B } \\
(\text { Oral }) \\
(\mathrm{n}=50)\end{array}$ & $\begin{array}{l}\text { Total } \\
(\mathrm{n}=100)\end{array}$ \\
\hline$\leq 7$ & $3(6 \%)$ & $5(10 \%)$ & $8(8 \%)$ \\
\hline$>7$ & $47(94 \%)$ & $45(90 \%)$ & $92(92 \%)$ \\
\hline APGAR & Score at 5 min & & \\
\hline$\leq 7$ & $1(2 \%)$ & 0 & $1(1 \%)$ \\
\hline$>7$ & $49(98 \%)$ & $50(100 \%)$ & $99(99 \%)$ \\
\hline
\end{tabular}

In group A, 97.3\% women had vaginal delivery within 24 hrs of induction while in group B it was $95.3 \%$ and the difference between the two groups was not found to be statistically significant. Only 3 women delivered more than 24 hrs after induction (1 in group A \& 2 in group B) (Table 4).

The indications foe emergency LSCS in both groups were fetal distress, failed induction and NPOL. MSL was seen in vaginal group only in 2 women. Commonest indication of LSCS in group A was fetal distress (58.3\%) and in group B it was NPOL (42.9\%). One case of failed induction in each group underwent LSCS (Table 5).

Nausea and vomiting were the most common side effect in both the groups, $34 \%$ in group A and $36 \%$ in group B and the difference in two groups was not statistically significant $(\mathrm{P}=0.834)$. Uterine hyperstimulation occurred in 9 women $(18 \%)$ in group $\mathrm{A}$ and in 2 women $(4 \%)$ in group $\mathrm{B}$ and This difference was statistically significant $(\mathrm{p}=0.041)$. similarly tachysystole and hypertonus were also significantly more in vaginal group as compared to oral group ( $\mathrm{P}=0.062,0.008)$. 4 women in vaginal group had fever as compared to none in oral group. None of women had diarrhoea or hyperpyrexia in both the groups. Few patients had more than one side effect. There was no statistically significant difference in occurrence of $\mathrm{PPH}$, vaginal and cervical tears in oral and vaginal misoprostol groups. Among the new borns 3 in group $A$ and 4 in group B had neonatal jaundice, 4 in group A developed transient tachypnoea but no incidence was seen in group B. 5 neonates in group A and 4 in group B required NICU care and difference was statistically insignificant $(\mathrm{P}=4.244)$ (Table 6).

Six percent of newborns in group A and $10 \%$ in group B had APGAR of $\leq 7$ but this difference was not statistically significant. All newborns had APGAR of $>7$ at 5 minutes of birth in group B and only 1 newborn had APGAR $<7$ in group A. Maximum number of newborns had birth weight in the range of $2.5-3 \mathrm{~kg}$ in both the groups $(\mathrm{P}=$ 2.59) (Table 7).

\section{DISCUSSION}

In various previous studies on safety and efficacy of vaginal and oral misoprostol different dosing regimens have been used. Higher doses of vaginal misoprostol were associated with shorter induction to delivery interval but more incidence of hyperstimulation was noted. ${ }^{2,5,10}$ Similarly different dosages of oral misoprostol have been used in literature like $300 \mu \mathrm{g}, 100 \mu \mathrm{g}, 50 \mu \mathrm{g}$, $20 \mu \mathrm{g}$ but WHO recommends the dose of oral misoprostol as $25 \mu \mathrm{g}$ to be administered every two hours to maximum of 5 doses. ${ }^{8,10-13}$ In our study we have compared $25 \mu \mathrm{g}$ vaginal misoprostol administered every 4 hours with oral misoprostol $25 \mu \mathrm{g}$ given every 2 hours for induction of labour. Maximum 3 doses were given in vaginal group and 5 doses in oral group. The dosing schedule of oral and vaginal misoprostol was kept like this in our study keeping in view the pharmacokinetics of misoprostol. ${ }^{14}$

The mean dose requirement of misoprostol was significantly higher in oral group $(2.88 \pm 1.08$ doses $)$ as compared to vaginal group ( $1.98 \pm 0.87$ doses) in our study and the difference was found to be statistically significant $(\mathrm{p}<0.001)$. It can be explained by the fact that oral misoprostol was repeated every 2 hourly as compared to vagnal misoprostol which was administered 4 hourly. In a study by Colon et al oral misoprostol $50 \mu \mathrm{g}$ initial dose followed after 4 hours by $100 \mu \mathrm{g}$ dose every 4 hours was compared with $25 \mu \mathrm{g}$ misoprostol 4 hourly and the mean number of misoprostol doses required was significantly higher in oral group as compared to vaginal group ( $\mathrm{p}$ $<0.01)^{5}$

No statistically significant difference was observed in duration of stages of labour between vaginal and oral misoprostol groups in our study, which is similar to those seen in a study by Cheng et al. ${ }^{10}$ There was no significant difference $(p=0.272)$ in the average interval from induction to delivery between the vaginal group $(14.42 \pm 5.01 \mathrm{hrs})$ and oral group $(13.14 \pm 5.5 \mathrm{hrs})$ in our study and similar results were observed in study by Colon et al5 where the difference in the interval between vaginal group $(18.0 \pm 8.3 \mathrm{hrs})$ and oral group $(19.3 \pm 6.7 \mathrm{hrs})$ was not significant. However, in oral group the interval between induction to active stage was shorter as compared to vaginal group $(7.42 \pm 4.2$ hours versus $10.30 \pm 5.1$ hours) and this was statistically significant $(\mathrm{p}=0.006)$.

In various previous studies which have compared oral and vaginal misoprostol for induction of labour using different dosing regimens reported lower caesarean rates in oral misoprostol group as compared to vaginal group. $5,9,10$ Similarly in our study, $76 \%$ of women in 
vaginal group and $86 \%$ in oral group delivered vaginally and $26 \%$ in vaginal group and $14 \%$ in oral group delivered by caesarean sections but this difference was not statistically significant $(\mathrm{p}=0.42)$. However, an Indian study by Jindal et al where they compared oral and vaginal misoprostol for induction of labour reported a significantly increased rate of caesarean section in oral misoprostol group $(\mathrm{p}=0.0462){ }^{15}$

Recent literature available has shown that oral misoprostol, as compared to vaginal misoprostol, is associated with lesser side effects such as hyperstimulation, hypertonicity, tachysystole but is associated with similar neonatal outcomes. In our study the incidence of hyperstimulation was significantly higher $(\mathrm{p}=0.025)$ in vaginal group as compared to oral group (18\% vs 4\%). This result was comparable to that observed in various other studies (Colon et al and Weeks et al, Cheng et al). ${ }^{5,9,10}$ Cheng et al in their study reported the incidence of hyperstimulation to be $0 \%$ in oral group compared with $11.3 \%$ in vaginal group. ${ }^{10}$ Uterine tachysystole in our study was less commonly seen in oral group (10\%) as compared to vaginal group (24\%) which is similar to that reported by How et al $(10 \%$ versus $32 \%)^{11}$

Although the number of women having fetal distress and hyperstimulation was more in vaginal group in our study as compared to oral group but there were no differences in neonatal outcomes as well as APGAR score at 1 and 5 min and NICU admission rates which is similar to the results seen in other studies. $5,10,12,15$

\section{CONCLUSION}

Our study has shown that oral misoprostol is equally efficacious as vaginal misoprostol for cervical ripening and induction of labour at term gestation. Oral misoprostol has a better safety profile than vaginal route as the incidence of hyperstimulation and tachysystole was significantly more in vaginal group, although the maternal and neonatal outcomes were not significantly different in both the groups and also considering the ease of oral administration, it should be preferred over vaginal misoprostol.

\section{Funding: No funding sources}

Conflict of interest: None declared

Ethical approval: The study was approved by the Institutional Ethics Committee of Government Medical College and Hospital, Chandigarh, India

\section{REFERENCES}

1. Cunningham FG, Leveno KJ, Bloom SL, Hauth JC, Gilstrp LC, Wanstrom KD. Williams Obstetrics. 22nded. New York: McGraw Hill Medical Publishing Division. 2005;535-42.
2. Danielsson KG, Marions L, Rodriguez A, Spur BW, Wong PY, Bygdeman M. Comparison between oral and vaginal administration of misoprostol on uterine contractility. Obstet Gynecol 1999;93:278-80.

3. Prysak M, Castronova FC. Elective induction versus spontaneous labour: a case-control analysis of safety and efficacy. Obstet Gynecol. 1998;92:47-52.

4. Seyb ST, Berka RJ, Socal ML, Dooley SL. Risk of cesarean delivery with elective induction of labour at term in nulliparous women. Obstet Gynecol. 1999;94:600-7.

5. Colón I, Clawson K, Hunter K, Druzin ML, Taslimi MM. Prospective randomized clinical trial of inpatient cervical ripening with stepwise oral misoprostol versus vaginal misoprostol. Am J Obstet Gynecol. 2005;192:747-52.

6. Induction of labor. NICE guidelines July 2008. Available http://www.nice.org.uk/nicemedia/live/12012/41256/ 41256.pdf. Accessed on 2 Nov, 2011.

7. ACOG committee opinion. New US Food and drug administration labeling of cytotec (misoprostol) use in pregnancy. Int J Gynecol Obstet. 2003;82:137-8.

8. WHO recommendations for induction of labour 2011, Available http://whqlibdoc.who.int/publications/2011/9789241 501156_eng.pdf. Accessed on 2 Nov, 2011.

9. Weeks A, Alfirevic Z. Oral misoprostol administration for labor induction. Clin Obstet Gynecol. 2006;49:658-71.

10. Cheng SY, Ming H, Lee JC. Titrated oral compared with vaginal misoprostol for labor induction: a randomized controlled trial. Obstet Gynecol. 2008;111:119-25.

11. How HY, Leaseburge L, Khoury JC, Siddiqi TA, Spinnato JA, Sibai BM. A comparison of various routes and dosages of misoprostol for cervical ripening and the induction of labour. Am J Obstet Gynecol. 2001;185:911-5.

12. Mehrotra S, Singh U, Gupta HP. A prospective double blind study using oral versus vaginal misoprostol for labour induction. J Obstet Gynecol. 2010;30:461-4.

13. Ayaz A, Saeed S, Farooq M, Ahmad I, Ali Bahoo M, Saeed M. Labour induction with randomized comparison of oral and intravaginal misoprostol in post date multigravida Women. Malaysian Journal of Medical Sciences. 2009;16:34-8.

14. Tang OS, Gemzell-Daielsson K. Int J Obstet Gynecol. 2007:99:160-7.

15. Jindal P, Avasthi K, Kaur M. A comparison of vaginal vs oral misoprostol for induction of labordouble blind randomized trial. The Journal of Obstetrics and Gynecology of India. 2011;6:538-42.

Cite this article as: Kaur P, Goel P, Takkar N, Huria A. Randomised controlled trial to compare safety and efficacy of vaginal versus oral route of misoprostol for induction of labour in term pregnancy with unfavourable cervix. Int J Reprod Contracept Obstet Gynecol 2015;4:1988-92. 